\title{
Ingeniería sostenible: nuevos objetivos en los proyectos de construcción
}

\section{Sustainable engineering: new objectives for construction projects}

\author{
Fernando Rodríguez*, Gonzalo Fernández*1 \\ * Universidad Politécnica de Madrid. ESPAÑA \\ Fecha de recepción: 26/01/2010 \\ Fecha de aceptación: 25/ 05/2010 \\ Resumen
}


This means that in recent years has begun to pose a new social and economic development model: Sustainable Development. The concept emerged in 1987 in the Brundtland report: O ur common future and in the Rio summit in 1992 it was assumed as the principle that it should chair the policies and strategies of the subsequent years, based on three pillars: society, environment and economy.

In parallel, already in 1972, the Stockholm Summit brought up a possible climate change that ends up in 1988 upon the establishment of an Intergovernmental Panel on Climate Change (IPCC) composed by the World Meteorological O rganization (W MO) and U nited N ations Environment Program (U NEP), which purpose is to evaluate the available scientific information about climate change and to evaluate the environmental and social economical impacts. After the latest report presented in 2007, it is clearer that: GHG concentration (green house gases) is increasingly in progress, that the climate system warming is an unmistakable fact (mean temperatures of air and oceans, general melting of ice sheet and snow, and the increase of mean sea level), that many natural systems are affected, and will be further affected by climate changes, being the sectors that contribute the most to the GHG increase: the energetic, transport and industry, the soil use and its usage changes (IPCC, 2007a; 2007b; 2007c). It is important to emphasize that the IPCC understands climate change as the change produced in the climatic system, due to a natural variability as well as the result of human activity, or both at the same time.

Sustainable development and climate change turn up as two new challenges having synergies and mutual interdependences. Human health, soil/aquatic ecology and social and economical systems are fundamental for human development and welfare, which in turn are sensitive and vulnerable to climate changes. At the same time, measures driven to sustainability positively affect the alleviation and adjustment to this climate change.

In the same was, IPCC was established in 1988, in year 2000 the Millennium Ecosystem Assessment Panel (MA) was created, in order to scientifically analyze the consequences from ecosystems changes in relation to human welfare. 
Conclusions demonstrate that our life style demand ecosystem resources and services far higher than the rate of resources regeneration; waste material are produced at a higher speed than the one our environment can absorb, the ecosystems capacity is decreasing, thus provoking changes in some cases irreversible; social and economical differences are increasing, between developed and undeveloped countries, and the environmental effects even promote such differences more (Millennium Ecosystem Assessment, 2005).

As well as social and political models are changing, the processes and methodologies employed by engineering must be improved. The introduction of sustainable engineering is a new challenge that intends to conciliate human requirements with the planet capability. In fact, if current patterns do not change, the expansion of construction will destroy, or at least disturb, natural and wild life habitats over $70 \%$ of land surface from now up to 2032, mainly because of population, economical activity and urbanization increase (UNEP, 2002).

Probably, there is no other sector with higher sustainability contribution potential than construction (Bakens, 2003). Construction sector employs approximately half the resources man consumes from nature; it is considered that $25 \%$ of waste material comes from construction and demolition (Alarcón, 2005) and more than $70 \%$ of worldwide energy moves around this sector (O teiza y Tenorio, 2007), thus making construction sector one of the activities influencing climate change the most. But not everything in construction is unsustainable. The water supply and sanitation, waste material management and a reliable secure infrastructure system meet society requirements, which are essential to the path towards a sustainable development (Siddiqui, 1997). These projects are to be conducted under Sustainable Construction criteria, because impacts on the social, environmental and economical sectors are excessively huge.

\section{O bjectives and scope}

As briefly discussed, it seems to be clear that processes employing human activities in general, and engineering in particular, cannot be sustained indefinitely. 
This study intends to take an approach regarding new objectives of sustainable construction, as well as to introduce the search of innovative methodologies and techniques helpful to achieve construction sustainability, and to propose a methodological management framework for sustainable management construction, from a point of view of an Integrated Management of Engineering Projects. We believe that a sustainable management may be the method for integrating in only one procedure what Bakens (2003) proposes: to join together different actors involved in the whole process (according to stages and activities), and introduce them into the same process, so as to achieve new objectives and requirements for sustainable development challenges and climate change, not forgetting the basic objective of the project (cost, term and quality), as well as developer performance.

A detailed analysis has been conducted on the existing documentation and a group of experts in integrated management projects and in sustainability applied to engineering topics has been created; in order to achieve a first step in approaching a life cycle project management, so as to foster and maximize sustainable opportunities and factors.

\section{Sustainable project management}

3.1 New requirements and objectives: Sustainable Construction

The main objectives of Integrated Project M anagement are: costs, quality and time; as well as performance and particular requirements for each project. But, it seems to be these requirements are not enough compared to new challenges posed by society, which demand a change of project approaches. There must be a strategic triple objective for the project, in accordance with the sustainable development concept, based on the environment (respect for natural resources and ecosystems capacities), society (social equitability and interaction by all parts involved) and economy (Figure 1). 


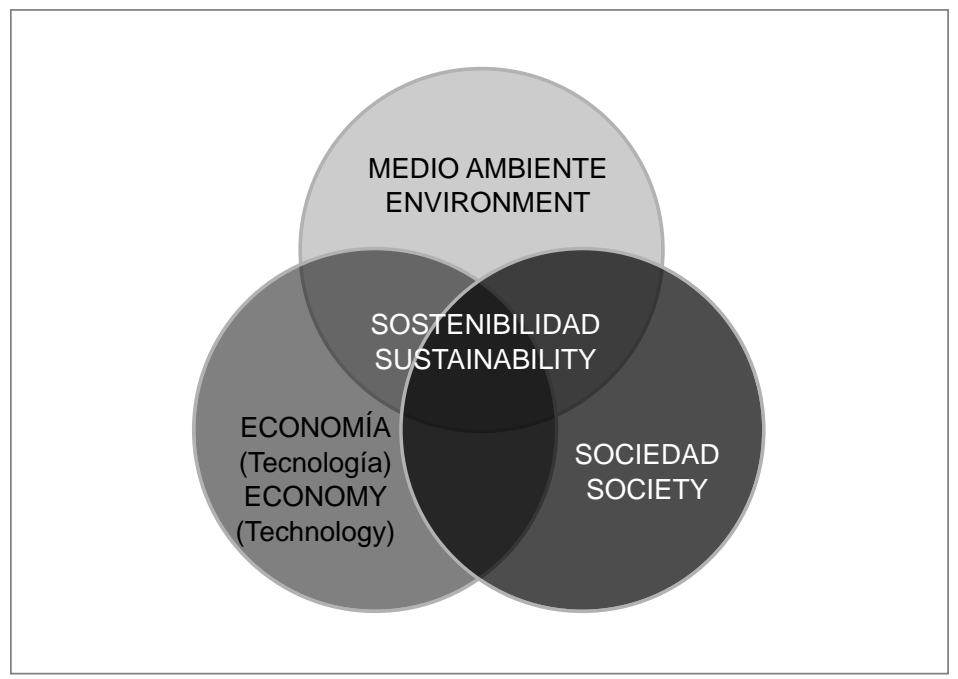

Figura 1. Las tres dimensiones de la ingeniería sostenible basado en (RAE, 2005) Figure 1. Three dimensions of sustainable engineering based on (RAE, 2005)

Sustainable development can also include the objectives planned by the IPCC on climate changes in view of a changing environment. In this way, release of $\mathrm{CO}_{2 \text { eq }}$ becomes especially important all way through the project life cycle (Sampedro, 2007) in order to minimize their releases, as well as projects adaptation and vulnerability to actual and future climate changes.

Those changes directly affect the way a civil engineering project is approached, where the most important aspects are:

- Life Cycle Assessment, LCA. According to some opinions, life cycle consists of designing and planning a project, from an idea conception until deconstruction or change of usage (from cradle to the grave), as per ISO 14040 and ISO 14044 regulations. However, as far as sustainable development concept is concerned, it seems to be pertinent to apply the cradle-to-cradle analysis to the design (Kholer and M offatt, 2003), i.e, planning thinking on the project life span, returning employed products to their original condition (materials, soil, etc.).

o Sustainable criteria application (environment, society and economy) as from planning and design stages (as conducted for costs, time and quality objectives), with the knowledge on new existing objectives by all involved parties. In this way, decision making process on different choices can be made not only counting with the common objectives of a project but under a more global and integrate vision of the environment. 
o The collaboration and interdisciplinary contribution (integration of all actors involved) from a sector, such as construction, where there are different stages and several parties involved.

o The importance of a social environment in construction, taking into account not only the physical user but also the indirect user, who will have to coexist directly with the new building throughout the project life cycle.

These new requirements, arising in accordance with sustainable development challenges, are the steps to be followed in order to achieve the necessary new balance between human activity in construction sector and environmental, social and economic sectors: the search for a sustainable construction.

\subsection{Available techniques and tools}

In order to achieve these new objectives, there are several researches and tools developed to approach a sustainable building construction. However, for infrastructure projects they are almost inexistent.

The major trend in building sector is the development of sustainable indication tools or systems to be used either to rank the building at different sustainable grades, or as a helpful technique for decision making process of project management. A search for sustainable tools working by means of indicator systems available worldwide, using different data bases as the one available on the CRISP website (Construction and City Related Sustainability Indicators), from U.S. D epartment of Energy "Building Technologies Programs", or the studies by Fowler and Rauch (2006), and by the International Energy Agency (IEA, 2001) have led to a total of 74 sustainable indicator systems in the world (Fernández, 2008). Some of the most important factors are shown in Table 1. 
Tabla 1. Sistemas de Indicadores de Sostenibilidad existentes en la edificación Table1. Sustainable Indicator Systems available for building sector

\begin{tabular}{|c|c|}
\hline Nombre del Sistema de Indicadores/Name of Indicator Systems & País de origen/Country of origin \\
\hline LEGOE & Alemania/Germany \\
\hline Green Star & Australia \\
\hline NABERS (National Australian Built Environment Rating System) & Australia \\
\hline TQ Building Assessment System (Total Q uality Building Assessment System) & Austria \\
\hline Sustainability indicator set for the construction sector & Austria \\
\hline Green Building Challenge (GBC): GBTool_05 - SBTool_07 & Canadá/Canada \\
\hline BEPAC (Building Environmental Performance Assessment Criteria) & Canadá/Canada \\
\hline Green Globes Canada (adaptado también a EEUU y Reino U nido/also adapted to USA and U nited Kingdom) & Canadá/Canada \\
\hline CEPAS (Comprehensive Environmental Performance Assessment Scheme) & China \\
\hline HK BEAM (Hong Kong Building Environmental Assessment Method) & China \\
\hline BEAT 2002 (Buliding Environmental Assessment Tool) & Dinamarca/Denmark \\
\hline N ordic set of environmental indicators for the property sector & $\begin{array}{c}\text { Dinamarca/D enmark, Finlandia/Finland, } \\
\text { Noruega/N orway, Suecia/Sweden, } \\
\text { Islandia/Island }\end{array}$ \\
\hline LEED (adaptado también a M exico, Canadá, India/also adapted to M exico, Canada, India) & EEUU/USA \\
\hline SPIRiT (Sustainable Project Rating Tool) & EEUU/USA \\
\hline VERDE (aplicación de SBTool a España/application of SBTool to Spain) & España/Spain \\
\hline MIVES (M odelo Integrado de Valor para Estructuras Sostenibles/Integrated Value M odel for Sustainable Structures) & España/Spain \\
\hline LEnSE (Label for Environmental, Social and Economic Buildings) & Europa/Europe (6thFP) \\
\hline CASBEE & Japón/Japan \\
\hline Green Building Rating System & Korea \\
\hline SBAT (Sustainable Building Assessment Tool) & Sudáfrica/South Africa \\
\hline $\begin{array}{l}\text { BREEAM (Building Research Establishment Environmental Assessment Method) -En proceso de adaptación a } \\
\text { otros países europeos como España/U nder adaptation process to other countries such as Spain- }\end{array}$ & Reino Unido/United Kingdom \\
\hline SPeAR & Reino U nido/United Kingdom \\
\hline
\end{tabular}

On the other hand, sustainability concept is being implemented by new regulations, as the Spanish legislation, where the emphasis is made on the application of the so called "sustainability criteria", as specifically indicated by first article in the Regulation of Hydrological Planning Regulation (2007) in Spain, by the Adapted Law for Evaluation of Environmental Impact Projects (2008) that aims to foster sustainable development; the Law of Evaluation on Plans and Program Effects (2006), created to promote a sustainable development on projects environmental issues leading to "Plans and Programs of Environmental Sustainability Reports": the Royal Decree which regulates the Production and $M$ anagement on Construction and Demolition Waste Material (2008), which intends to achieve a more sustainable development of construction activities; 
and at last, the New Instruction for Structural Concrete (ISC), (2008) that introduces a new optional annex to calculate the Sustainability Contribution from Structural Concrete to sustainability, ICES (Aguado et al., 2008). Therefore, it seems there is a well-grounded need of application of sustainability criteria on civil engineering projects.

For infrastructure projects, there are no even integral sustainability assessment systems, although there are some only related to environment (one of the columns for sustainability). O nly one proposal for Sustainability Appraisal in Infrastructure Projects has been found, named SU SAIP (U gwu et al., 2006) subsequently applied to construction industry in South Africa (U gwu and Haupt, 2007), which is based on indicators provided by interviews and surveys conducted to parties involved with the project life cycle, selecting those most important according to interviewees. Besides, there is an assessment index for infrastructures in Canada (D asgupta and Tam, 2005), the so called Technical Sustainability Index (TSI). It also includes models for selection of suppliers and providers related to construction projects (Chen et al., 2008), from a sustainability point of view.

There is no doubt that the existence of such indicator systems for building as well as scarcely for infrastructure constructions is a step forward, but those systems are generally subjective and with a high uncertainty degree (Seo et al., 2004), where the goal is to achieve a higher score, perhaps loosing the opportunity to make the project more sustainable, since the indicator does not reflect a solid characteristic and distinction from the project in particular.

Construction is a very particular industry. Each project is designed and built differently from others: it is singular. This complicates the creation of indicators valid for all projects. There are different typologies, activities, parties involved, situations, locations and different performances that make every single project one of a kind. That is why we believe that, even when an indicator system is a valid tool helping decision making process faced to choices analysis, it is not a complete methodological process where all sustainability opportunities are analyzed assessing its profitability application on a given project. 
An effective solution as far as energy in building site is concerned; will not yield the expected results, unless it is appropriate for the location climate conditions; it must be completely detailed, installed and duly managed and the complexity level must be understood by the managers and users of the building (Brunn, 2003).

There is only one advance in this building sector, which is based on the value engineering that deals with sustainability management in building projects. It is the so called tool CVEP, Continue Value Enhancement Process (Pulaski and Horman, 2005) that comes out as a response to such need of managing a project in a constructive and sustainable way. The only problem is that it cannot be standardized, since it is only applicable to the building sector, and it is only compatible with LEED indicators systems. Anyway it is an important advance in the process towards the creation of a new sustainable management.

3.3 M ethodological framework proposed for sustainable management within DIP

Based on the CVEP proposed by Pulaski in his doctorate thesis, and on the Integrated Project $M$ anagement in processes such as risk management (PMI, 2004), the proposal suggest the creation of a new methodological framework where sustainable management for a construction project can be dealt as opportunities for such project and to study the convenience or inconvenience of applying sustainability indicators that identify themselves with the design, in accordance with the developer goals and the original objectives of the project (costs, time and quality).

Stages in this proposed methodology are five: management planning, identification of sustainable factors, analysis (quality and/or quantity), response and control; following a repeated and cyclic process that begins in the conception stage of the project (Figure 2). 


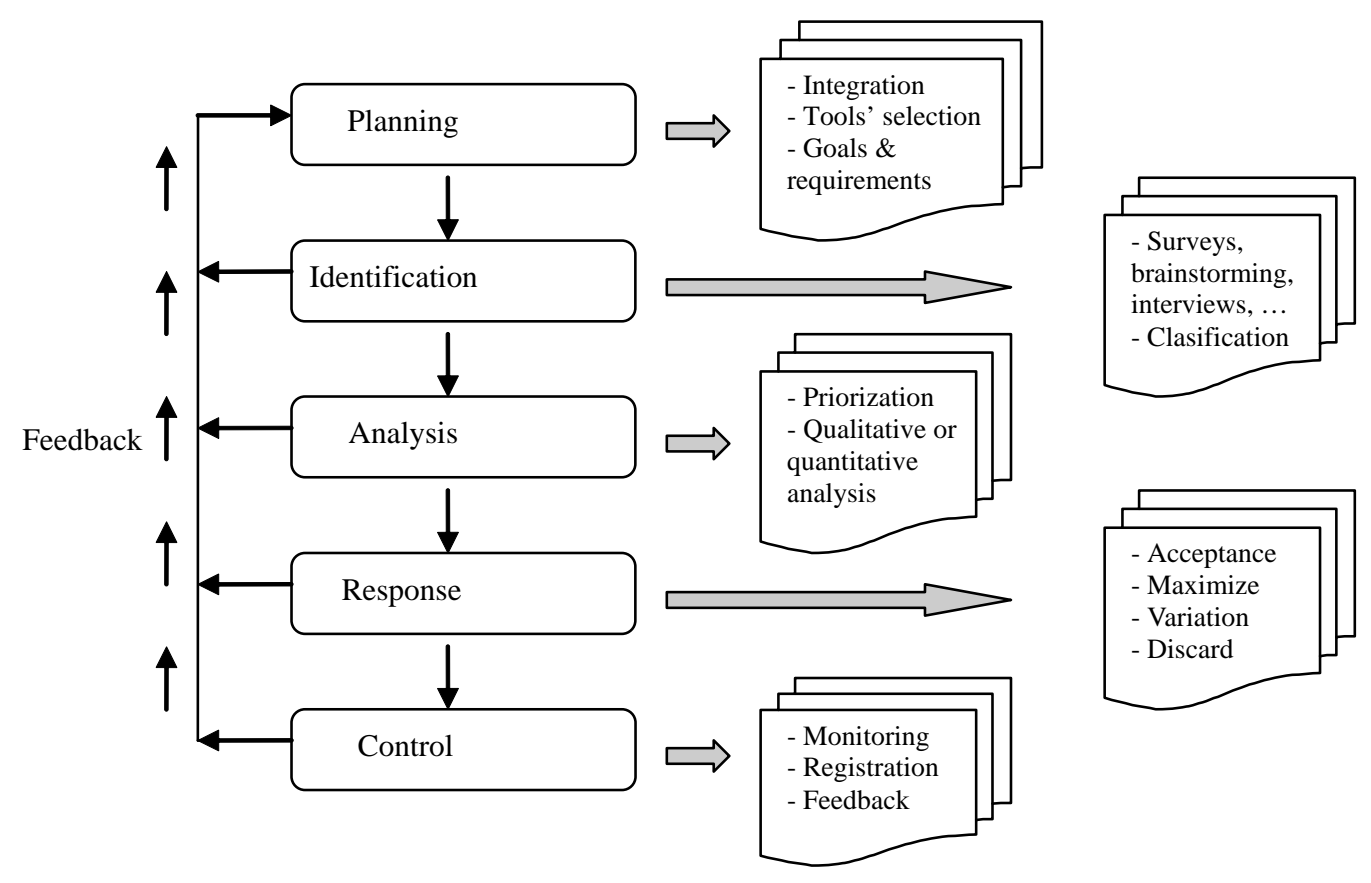

Figura 2. Flujo del proceso de gestión sostenible de proyectos de construcción Figure 2. Sustainable management flow chart for construction projects

The process begins with the consistent planning for project interaction by the sustainable management team of experts in the Integrated Project Management, by selecting the objectives in agreement with the other teams, and by planning and distributing roles and responsibilities for the group. Techniques and tools to be used by the team will be selected during different stages in the process.

For sustainable factors identification, the use of employed techniques for project management is proposed for risks identification in accordance with the standards provided by the Project Management Institute (PMI), by the International Project Management Association (IPMA), Project Risk Analysis \& Management (RAM), but in this case for opportunities identification and sustainability indicators. So techniques applied will be surveys, interviews to experts; the creation of work teams to develop a controlled brainstorming (also considered by Pulaski's study, 2005, for pentagon rehabilitation), 
the past experiences of the team in other sustainable managements (group assets and files), the review of existing documentation for similar projects or the identification by means of a separate structure of project tasks (Sustainable Breakdown Structure, SBS $_{\text {genérica). The }}$ output of the project consists of a classification of opportunities and identified indicators in accordance with the relative importance of them in the project, which may be introduced and ranked as the $\mathrm{SB}_{\text {real }}$ tool. The main purpose of this identification process is the selection of all possible opportunities that may improve the project sustainability. Indicator systems may be the input of this process.

The same as with identified risks, it is necessary to set priorities and analyze sustainable opportunities. It is logical that not all the opportunities will be applicable to this project. Based on Pulaski proposal, the analysis on each identified opportunity can be conducted in accordance with its viability in the project, impact on the project objectives, promoter requirements and sustainable objectives. A graphic chart on this analysis can be made by means of a spider graph (Figure 3), where the impact of the possible application of an opportunity over a real project is shown: 0.5 means that the objective is not affected by the new opportunity, and less than this value represents a negative impact, higher than 0.5 means the impact is positive. In this way, it is possible to obtain an idea whether the identified element is applicable to the project, depending on the positive or negative effect on mentioned objectives (decision making).

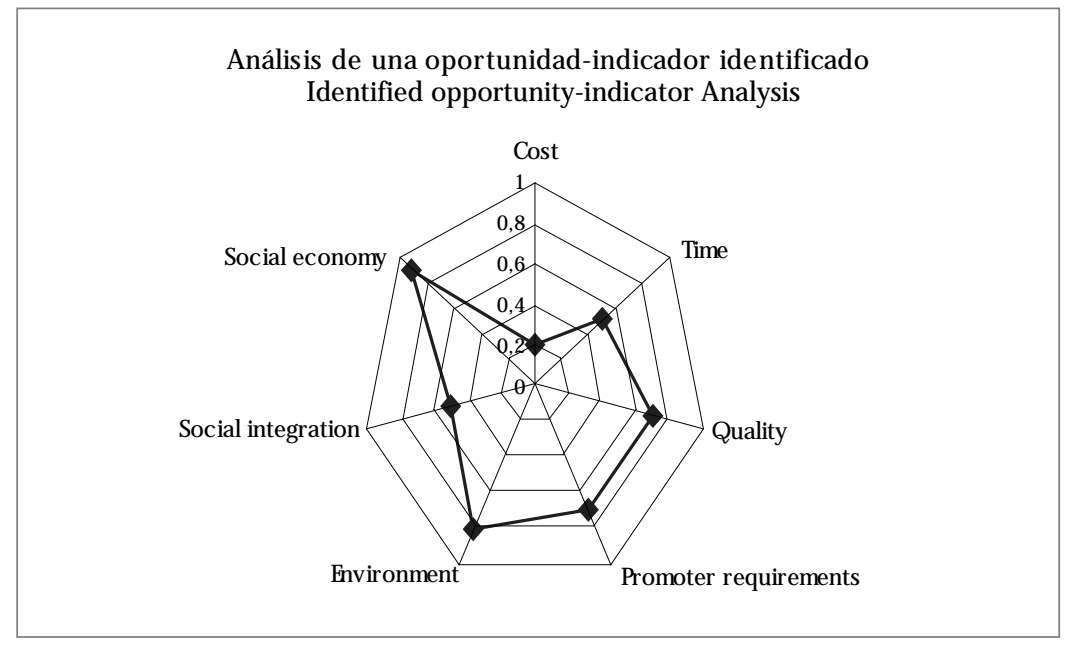

Figura 3. Ejemplo de evaluación de una oportunidad atendiendo a los objetivos del proyecto, los requisitos del promotor y la construcción sostenible

Figure 3. Example of an O pportunity Assessment focused on the project objectives, promoter requirements and sustainable construction 
Besides this tool, in the stage of opportunities analysis, some other tools can be employed such as interviewing experts to obtain their assessments; or to apply a sensitivity analysis on different identified opportunities in order to achieve those contributing to bring higher profits to the project with less economical efforts or higher constructive facilities. The selection of one technique over others will depend on the kind of project, the technical capability of the managing team and on the objectives outlined by the promoter in each case (selected in the planning stage).

The outputs of the analysis process will yield important information to make a decision or to provide a response on the applicability of the identified element in the process. Thus response or answer provided for each identified and analyzed sustainable factor will be:

o The acceptance of the proposal: introduction and application of the opportunity into the project. o Maximization of its qualities

o Proposal for changes of the opportunity, in order to increase the positive impacts and decrease negative impacts.

o Discarding the opportunity

A file of sustainability factors rises as a result of this process, for the adequate control during the project life cycle, as well as for employing it in the execution of future similar projects of this team. Besides, in the control stage some indicator systems can be used to verify the degree of sustainability reached by a building or infrastructure in accordance with changes to be proposed in the design stage, as per sustainability criteria to be achieved.

\section{Conclusions}

This article has intended to measure the state of knowledge of techniques and methodologies currently employed in construction, in order to achieve new sustainability objectives. Besides, a methodology has been proposed to include such techniques and may be useful for project management, facilitating a sustainable management, reaching the outlined objectives, but not forgetting the original objectives: performances costs, quality and time. 
The idea of developing a methodology for project sustainable management is exactly based on the belief that indicator systems are very useful for decision making and/or certification, but they cannot represent the wide variability and requirements from different engineering projects in the construction sector. By making a correct identification and analysis on different opportunities and indicators of each particular project, sustainable factors that can be more profitable and effective for one or another similar project can be easily identified. However, sustainable indicator systems are still a useful tool for objective assessments by third parties in construction projects.

\section{Referencias/References}

Aguado A., Alarcón B. y Manga R. (2008), Razón de ser del anejo ICES de la EHE y características del mismo. Revista Cemento y Hormigón 913, 16-23.

Alarcón D. B. (2005), Modelo Integrado de Valor para Estructuras Sostenibles. Thesis, Universitat Politècnica de Catalunya, Escola Tècnica Superior D'Enginyers de Camins, Canals i Ports, Spain.

Bakens W. (2003), Realizing the sector's potencial for contributing to sustainable development. UNEP Industry and Environment, April - September, 9-12.

Brunn R. (2003), Sustainable building services in developing countries: the challenge to find "best-fit" Technologies. UNEP Industry and Environment, April-September, 46-52.

Chen Z., Li H., Ross A., Khalfan M.M.A. and Kong S.C.W. (2008), Knowledge-D riven AN P Approach to Vendors Evaluation for Sustainable Construction. Journal of Construction Engineering and Management, 134 (12) December, 928-941.

CRISP (Construction and City Related Sustainability Indicators): http://crisp.cstb.fr

Dasgupta S. and Tam E.K.L. (2005), Indicators and framework for assessing sustainable infrastructure. Canadian Journal of Civil Engineering, 32, 30-44.

Fernández Sánchez G. (2008), Análisis de los sistemas de indicadores de sostenibilidad: Planificación urbana y proyectos de construcción. Escuela Técnica Superior de Ingenieros de Caminos, Canales y Puertos, Universidad Politécnica de Madrid, España. Fowler K.M. and Rauch E.M. (2006), Sustainable Building Rating Systems. Department of Energy, U nited States of America, July 2006. IEA (International Energy Agency) and Energy Conservation in Buildings and Community Systems Programme (2001), Directory of Tools, a Survey of LCA Tools, Assessment Frameworks, Rating Systems, Technical Guidelines, Catalogues, Checklists and Certificates, Annex 31 "Energy-related Environmental Impact of Buildings", Canada Mortgage and Housing Corporation. IPCC (2007a), Climate Change 2007: The Physical Science Basis. Contribution of Working Group I to the Fourth Assessment Report of the IPCC. [Solomon, S., D. Q uin, M. Manning, Z. Chen, M. Marquis, K.B. Averyt, M. Tignor and H.L. Miller (eds)], Cambridge U niversity Press, Cambridge, U nited Kingdom and New York, NY, USA.

IPCC (2007b), Climate Change 2007: Impacts, Adaptation and Vulnerability. Contribution of Working Group II to the Fourth Assessment Report of the IPCC. [Parry, M., Canziani, O.,Palutikof, J., van der Linden, P., Hanson, C. (eds)], Cambridge U niversity Press, Cambridge, United Kingdom and New York, NY, USA.

IPCC (2007C), Climate Change 2007: Mitigation of Climate Change. Contribution of Working Group III to the Fourth Assessment Report of the IPCC. [M etz, B., Davidson, O., Bosch, P., Dave, R., M eyer, L. (eds)], Cambridge University Press, Cambridge, U nited Kingdom and N ew York, NY, USA.

Kholer N. y M offatt S. (2003), Life-cycle analysis of the built environment. UNEP Industry and Environment, April-September, 17-21.

Millenium Ecosystem Assessment (2005) Ecosystems and Human Well-being. The Millenium Ecosystem Assessment, Island Press, Washington, DC. 
O teiza I. and Tenorio J.A. (2007), La innovación en las técnicas, los sistemas y los materiales de construcción. Jornada J7: Evaluación de la sostenibilidad en la Edificación, XVII Edición Curso de Estudios M ayores de la Construcción (CEM CO Instituto Eduardo Torroja, Madrid.

PMI (Project Management Institute) (2004), A Guide to the Project Management Body of Knowledge (PM BoK Guide), third edition. Pulaski M. and Horman M. (2005), Continuous Value Enhancement Process. Journal of Construction Engineering and M anagement, 131 (12), 1274-1282.

Pulaski M. (2005), The alignment of sustainability and constructability: a continuous value enhancement process, Thesis in Architectural Engineering, The Pennsylvania State University, The Graduate School, Department of Architectural Engineering, May 2005.

RAE (2005), Engineering for sustainable development Guiding Principles. The Royal Academy of Engineering. September, 2005.

Sampedro A. (2007), Las implicaciones del protocolo de Kioto en la ingeniería civil. V Congreso Nacional de Ingeniería Civil: Desarrollo y sostenibilidad en el marco de la ingeniería. Sevilla.

Seo S., Aramaki T., H wang Y. and Hanaki K. (2004), Fuzzy Decision-Making tool for Environmental Sustainable Buildings. Journal of Construction Engineering and Management 130 (3) May/June, 415-423.

Siddiqui S. (1997), Infrastructure, Sustainable Development \& Society. Thesis, Department of Civil Engineering and Applied M echanics. McGill University. Montreal, Canada.

U gwu O. O., Kumaraswamy M. M., Wong A. and Ng S. T. (2006), Sustainability appraisal in infrastructure projectos (SU SAIP) Part 1. Development of indicators and computational methods. Automation in Construction, 15 (2), $239-25$.

U gwu 0.O. and Haupt T.C. (2007), Key performance indicators and assessment methods for infrastructure sustainability-a South African construction industry perspective. Building and Environment 42, 665-68.

UNEP/Earthscan (2002), Global Environmental O utlook 3, London. 